\title{
Effect of corn silage harvest maturity and concentrate type on milk fatty acid composition of dairy cows
}

\author{
N. A. Khan, ${ }^{* 1}$ T. A. Tewoldebrhan, ${ }^{*}$ R. L. G. Zom, $†$ J. W. Cone, ${ }^{*}$ and W. H. Hendriks ${ }^{\star} \mp$ \\ *Animal Nutrition Group, Department of Animal Sciences, Wageningen University, PO Box 338, 6700 AH Wageningen, the Netherlands \\ †Wageningen UR Livestock Research, Animal Sciences Group, PO Box 65, 8200 AB Lelystad, the Netherlands \\ ¥Faculty of Veterinary Medicine, Utrecht University, PO Box 80.163, 3508 TD Utrecht, the Netherlands
}

\begin{abstract}
The variation in maturity at harvest during grain filling has a major effect on the carbohydrate composition (starch:NDF ratio) and fatty acid (FA) content of corn silages, and can alter the FA composition of milk fat in dairy cows. This study evaluated the effect of silage corn (cv. Atrium) harvested and ensiled at targeted DM contents of 300,340, 380, and $420 \mathrm{~g} / \mathrm{kg}$ of fresh weight and fed to dairy cows in combination with a highly degradable carbohydrate (HC) or lowdegradable carbohydrate concentrate, on the nutrient intake, milk yield, and composition of milk and milk fat. Sixty-four multiparous Holstein-Friesian dairy cows in their first week of lactation were assigned to the 8 dietary treatments according to a randomized complete block design. The 8 dietary treatments consisted of a factorial combination of the 4 corn silages and the 2 concentrates. Corn silages were offered ad libitum as part of a basal forage mixture, whereas the concentrates were given at the rate of $8.5 \mathrm{~kg}$ of $\mathrm{DM} /$ cow per day during the 15-wk experimental period. Dry matter, crude protein, and energy intakes did not differ across the corn silages. However, the intake of starch increased, and those of NDF and C18:3n-3 decreased with increasing maturation. Milk yield and composition were not different across the corn silages. Yield $(\mathrm{kg} / \mathrm{d})$ of milk, protein, and lactose was higher for low-degradable carbohydrate compared with $\mathrm{HC}$ concentrate-fed groups. Increasing maturity of corn silages decreased the content of C18:3n-3 and total n-3 and increased the n-6:n-3 ratio in milk fat. Concentrate type significantly altered the composition of all trans FA, except C18:2 trans-9,12. Inclusion of the $\mathrm{HC}$ concentrate in the diets increased the contents of all C18:1 trans isomers, C18:2 cis-9,trans-11, and C18:2 trans-10,cis-12 conjugated linoleic acid in milk fat. Milk fat composition was strongly influenced by the stage of lactation (wk 3 to 10). The content of all even short- and medium-chain
\end{abstract}

Received July 7, 2011.

Accepted November 15, 2011.

${ }^{1}$ Corresponding author: nak126@gmail.com
FA changed with lactation, except C8:0 and C10:0. The content of $\mathrm{C} 12: 0, \mathrm{C} 14: 0$, and $\mathrm{C} 16: 0$ and total saturated FA increased and the content of C18:0, C18:1 cis total, and total cis monounsaturated FA decreased with lactation. Maturity of the corn silages at harvest did not affect the production performance of dairy cows, but resulted in a decreased content of C18:3n-3, total n-3, and an increased n-6:n-3 ratio in the milk fat of dairy cows.

Key words: corn silage, harvest maturity, dairy cow, milk fatty acid

\section{INTRODUCTION}

Silage corn is a major forage component in the ration of dairy cows, under most dietary regimens. The crop has a relatively stable yield, high energy content, good ensiling characteristics, and inclusion of corn silages in grass- or grass silage-based diets can increase feed intake, milk yield, and milk protein content (Phipps et al., 1995; O'Mara et al., 1998; Phipps et al., 2000). As a result, like many other European countries, the area used for silage corn production in the Netherlands has increased from $5.0 \times 10^{3}$ ha in 1970 to $2.4 \times 10^{4}$ ha in 2004 (Schroeder, 1998; Barrière et al., 2006). Due to their high consumption, forages in fresh or ensiled form are also major sources of PUFA (C18:3n-3, C18:2n-6) in dairy cow rations, and high PUFA-containing forages can be used to favorably modulate milk FA composition (Dewhurst et al., 2006; Elgersma et al., 2006).

Corn silages are high in starch and C18:2n-6 (0.52 \pm $0.10 \mathrm{~g} / \mathrm{g}$ of total FA), whereas grass silages are high in NDF and C18:3n-3 (0.58 $\pm 0.16 \mathrm{~g} / \mathrm{g}$ of total FA; Khan et al., 2012). Inclusion of corn silages in grass-based rations of dairy cows increases the level of trans FA, mainly at the expense of their cis isomers and lowers the content of beneficial C18:3n-3 causing an elevated n-6:n-3 PUFA ratio in milk fat (Havemose et al., 2004; Shingfield et al., 2005; Kliem et al., 2008). Under normal rumen conditions, hydrogenation of C18:2n-6 in corn silage mainly results in an increased concentration of cis-9,trans-11 conjugated linoleic acid (CLA) and C18:1 trans-11 (Chilliard et al., 2001), which are 
considered potentially beneficial to human health. Moreover, a combination of corn silages with highly degradable carbohydrate concentrates further increases the content of trans $\mathrm{FA}$ and shifts the rumen biohydrogenation pathway toward the production of C18:1 trans-10 at the expense of C18:1 trans-11 (Piperova et al., 2000; Nielsen et al., 2006). A high level of trans FA, particularly with trans-trans double bonds, have been reported to increase the risk of coronary heart disease and diabetes (Ascherio et al., 1999; Lemaitre et al., 2002). In addition, increasing the content of n-3 PUFA and decreasing the n-6:n-3 PUFA ratio in milk fat of dairy cows fed corn silages, may be beneficial for human health (Kliem et al., 2008).

In the Netherlands, but also elsewhere in Europe (Phipps et al., 2000), silage corn is harvested at a wide range of maturation, with the whole crop DM content ranging from 250 to $450 \mathrm{~g} / \mathrm{kg}$ of fresh weight $(\mathbf{F W})$. These differences in maturity at harvest during grain filling result in considerable variation in FA content (Khan et al., 2011) and carbohydrate composition (starch:NDF ratio) of corn silages (Bal et al., 2000; Phipps et al., 2000). These changes can influence both the rumen environment and microbial hydrogenation of unsaturated FA (Shingfield et al., 2005; Nielsen et al., 2006), and as a consequence the milk FA composition of dairy cows.

The aim of this experiment was to evaluate the effect of corn silages ensiled at different maturities in combination with concentrates with a highly or lowdegradable carbohydrate content on nutrient intake, milk yield, milk composition, and milk FA composition in early lactating dairy cows, to develop practical nutritional strategies to improve milk FA composition of dairy cows fed corn silages. We hypothesized that the variation in FA composition of corn silages as well as the amount and composition of carbohydrates in the different diets can affect milk FA composition of dairy cows.

\section{MATERIALS AND METHODS}

\section{Silages}

Corn silages were prepared from a single crop (cv. Atrium; Force Limagrain Nederland BV, Rilland, the Netherlands), sown on clay soil on April 20, 2009, at a density of 100,000 seeds/ha (10 plants $\left./ \mathrm{m}^{2}\right)$ and row spacing of $0.75 \mathrm{~m}$, at the research facility of Wageningen University and Research Center, Lelystad, the Netherlands $\left(52^{\circ} 5^{\prime} \mathrm{N}\right.$ and $\left.5^{\circ} 5^{\prime} \mathrm{E}\right)$. The crop was fertilized with $50 \mathrm{t}$ of cattle slurry/ha (containing $4 \mathrm{~kg}$ of N/t and $1.3 \mathrm{~kg}$ of $\left.\mathrm{P}_{2} \mathrm{O}_{5} / \mathrm{t}\right), 30 \mathrm{~kg}$ of $\mathrm{N} / \mathrm{ha}$, and $30 \mathrm{~kg}$ of $\mathrm{P}_{2} \mathrm{O}_{5} /$ ha as ammonium phosphate. The corn was harvested and ensiled at target DM contents of 300 (MS30), 340
(MS34), 380 (MS38), and 420 (MS42) g/kg of FW. No additives were used to improve the ensiling process. To determine the targeted harvest DM, 5 plants from 5 randomly selected spots in each cross-section of each plot were sampled twice weekly, chopped, and dried in an oven at $103^{\circ} \mathrm{C}$ for $24 \mathrm{~h}$. The frequency was increased to daily sampling when the difference with the target DM content was less than $30 \mathrm{~g} / \mathrm{kg}$. The actual DM contents of the crop were close to the targeted DM contents (Table 1). All silages were made with the same precision chop harvester (John Deere 7750; John Deere \& Co., Mannheim, Germany) using identical machine settings. The theoretical length of cut was $6 \mathrm{~mm}$ and roll-clearance of the kernel processor was $1 \mathrm{~mm}$, to ensure that all kernels were sufficiently crushed. The corn silages were stored in bunker silos and compacted with a heavy weight tractor and a wheel loader. The silages were airtight sealed with 2 layers of $0.15-\mathrm{mm}$ polyethylene plastic sheets, and covered with a $20-\mathrm{cm}$ thick sand load. The total silage-clamp was covered with a protection sheet being held down with sand bags.

The grass silage was prepared from first-cut perennial ryegrass (Lolium perenne L.) cultivars (BG3; Barenbrug Holland BV, Oosterhout, the Netherlands), mowed on May 1, 2009 with a disc mower and conditioner. The mower-conditioner gently removed the waxy layer of leaves and stems of the grass with some additional crimping to enhance the drying process. The grass was wilted for $36 \mathrm{~h}$ with $20 \mathrm{~h}$ of sun, and tedded twice in the field. The average daytime temperature was $20.4^{\circ} \mathrm{C}$ and the average nighttime temperature was $7^{\circ} \mathrm{C}$. The grass was ensiled in bunker silos, compacted and sealed, as described for corn silages.

\section{Experimental Design, Animals, and Diets}

Sixty-four multiparous Holstein-Friesian dairy cows were assigned to 8 dietary treatments $(n=8$ cows per dietary treatment), according to a randomized complete block design with repeated measures. Cows were distributed over the 8 blocks to balance for parity, milk yield during previous lactation, BW, and DMI among blocks. The 8 dietary treatments consisted of a factorial combination of the 4 corn silages (MS30, MS34, MS38, and MS42) and 2 types of concentrate: a highly degradable carbohydrate [HC; low NDF, high watersoluble carbohydrates (WSC)] and low-degradable carbohydrate (LC; high NDF and low WSC) concentrate. Cows were adapted to the experimental diets and feeding regimens just after calving and data collection started the second week after calving until $17 \mathrm{wk}$ after calving (March 30 to August 27, 2010).

The 4 corn silages were offered ad libitum as part of a forage mixture, which contained $61 \%$ corn silage, $28 \%$ 
Table 1. Harvest dates, DM content, and yield of silage corn at the targeted harvest DM contents of 300 (MS30), 340 (MS34), 380 (MS38), and 420 (MS42) $\mathrm{g} / \mathrm{kg}$ of fresh weight, and weather conditions during the preceding period after flowering

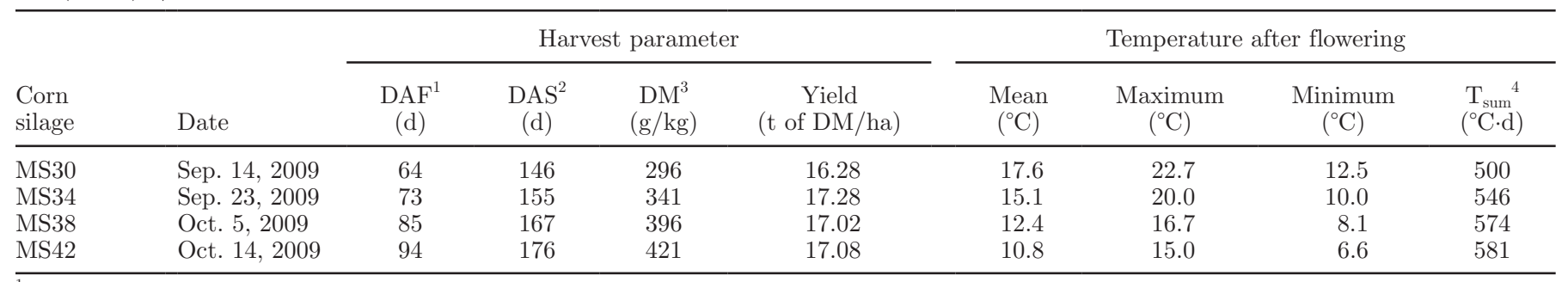

${ }^{1}$ Days after flowering.

${ }^{2}$ Day after sowing.

${ }^{3}$ Crop DM content at harvest $(\mathrm{n}=10)$.

${ }^{4}$ Temperature sum $\left({ }^{\circ} \mathrm{C} \cdot \mathrm{d}\right.$, with a base temperature of $10^{\circ} \mathrm{C}$; Sibma, 1987) after flowering.

grass silage, $10 \%$ soybean meal, $0.45 \%$ mineral mixture (190 g of Ca, $45 \mathrm{~g}$ of $\mathrm{Na}, 120 \mathrm{~g}$ of $\mathrm{Mg}, 1,200 \mathrm{mg}$ of $\mathrm{Cu}$, 2,500 $\mathrm{mg}$ of $\mathrm{Zn}, 3,000 \mathrm{mg}$ of $\mathrm{Mn}, 120 \mathrm{mg}$ of I, and 34 $\mathrm{mg}$ of $\mathrm{Se})$ and $0.34 \%$ salt $(\mathrm{NaCl} ; 380 \mathrm{~g}$ of $\mathrm{Na}$ and 570 $\mathrm{g}$ of $\mathrm{Cl}$ ) on a $\mathrm{DM}$ basis. The concentrates (Table 2) were given at a rate of $8.5 \mathrm{~kg}$ of $\mathrm{DM} / \mathrm{cow}$ per day. The forage mixtures were prepared each day using a selfpropelled mixer equipped with a cutter loader system and an electronic weighing unit. The forage mixtures were fed in individual weighing troughs (Insentec BV, Marknesse, the Netherlands) containing data loggers, which recorded the forage intake after each visit for individual cows. The troughs were continuously accessible except during the milking period. The concentrates were fed individually using 3 transponder-controlled concentrate dispensers, and dispensed at a rate of 0.3 $\mathrm{kg} / \mathrm{min}$. The total daily allowance of the concentrates was partitioned over 6 consecutive time windows of 4 $\mathrm{h}$ each. The 8 dietary treatments were formulated to be isonitrogenous and isoenergetic and only differed in corn silage maturity and type of the concentrates. The nutrient requirements of the cows were calculated according to the Central Bureau for Livestock Feeding (The Hague, the Netherlands; CVB, 2007) estimates.

\section{Data Recording and Sampling}

Fresh forage mixtures were sampled daily, the ingredients of the forage mixtures twice per week, and concentrates once after delivery of a new batch for DM analysis. For chemical and FA analysis, samples of individual feedstuffs and the forage mixture were taken weekly and frozen immediately at $-20^{\circ} \mathrm{C}$. Dry matter intake and milk yield of individual cows were recorded daily throughout the experiment, with cows milked twice daily at 0600 and $1800 \mathrm{~h}$. Milk samples were taken weekly from 4 consecutive milkings. The morning and evening milk samples were pooled (1:1 ratio) separately to obtain 2 composite milk samples.
The samples were stored at $4^{\circ} \mathrm{C}$ until analyzed for fat, protein, lactose, and milk SCC. For FA analysis, subsamples of milk from wk 3,5 , and 10 were taken and immediately stored at $-20^{\circ} \mathrm{C}$. To measure changes in $\mathrm{BW}$, the precalving $\mathrm{BW}$ were recorded weekly, whereas postcalving BW were recorded automatically twice per day at the entrance of the milking parlor. The BCS of each cow was recorded weekly by an experienced observer on a scale from 1 (thin) to 5 (fat) with 0.25-point intervals (Edmonson et al., 1989).

\section{Chemical Analysis}

All feed samples were freeze-dried and ground to pass through a 1-mm screen, and analyzed for DM, ash, $\mathrm{CP}$, crude fat, NDF, ADF, ADL, starch, sugar, and FA content. The DM content was determined by oven drying at $103^{\circ} \mathrm{C}$ for $24 \mathrm{~h}$ [International Organization for Standardization (ISO) 6496; ISO, 1999a], ash after incineration at $550^{\circ} \mathrm{C}$ (ISO 5984; ISO, 2002) and CP was determined using the Kjeldahl method (ISO 5983; ISO, 2005) for $\mathrm{N}$ and multiplication by 6.25 . Acid detergent fiber and ADL contents were determined according to Van Soest (1973). Neutral detergent fiber was analyzed according to Van Soest et al. (1991), with some modification as described by Khan et al. (2009). Crude fat content was determined using the Berntop method with pre-acid hydrolysis (ISO 6492; ISO, 1999b). Sugars were determined as described by Van Vuuren et al. (1993). The starch content was determined as glucose, using the amyloglucosidase method (ISO 5914; ISO, 2004) after an initial extraction of the samples with $40 \%$ ethanol (to remove the sugar fraction). Ammonia content was determined according to the Berthelot method as modified by Scheiner (1976). The feeding values, in vitro OM digestibility (OMD), $\mathrm{NE}_{\mathrm{L}}$, true protein digestion in the small intestine (DVE), and degraded protein balance in the rumen (OEB), were determined using near-infrared reflectance spectrometry by a commercial laboratory 
Table 2. Ingredient composition of the concentrates

\begin{tabular}{lrr}
\hline & \multicolumn{2}{c}{ Concentrate $^{1}$} \\
\cline { 2 - 3 } Ingredient $(\mathrm{g} / \mathrm{kg})$ & $\mathrm{LC}$ & $\mathrm{HC}$ \\
\hline Wheat & 0.00 & 35.71 \\
Corn gluten meal & 75.00 & 25.00 \\
Wheat middlings & 43.89 & 50.00 \\
Wheat gluten meal & 113.99 & 100.00 \\
Beet pulp, 15-20\% sugar & 126.42 & 100.00 \\
Citrus pulp & 50.00 & 162.19 \\
Beet vinasse, CP $>250 \mathrm{~g} / \mathrm{kg}$ & 66.64 & 80.00 \\
Beet vinasse, CP $<250 \mathrm{~g} / \mathrm{kg}$ & 39.20 & 10.00 \\
Cane molasses & 0.00 & 29.20 \\
Soybean hulls & 55.33 & 0.00 \\
Soybean meal, solvent extracted & 124.37 & 116.49 \\
Extracted linseed & 11.79 & 10.00 \\
Coconut expeller & 50.00 & 50.00 \\
Canola meal & 27.49 & 69.13 \\
Canola meal, formaldehyde treated & 24.92 & 21.14 \\
Palm kernel expeller & 175.0 & 128.65 \\
Magnesium oxide & 3.88 & 4.23 \\
Mineral and vitamin mixture & & 3.92 \\
Calcium carbonate & 3.92 & 2.17 \\
Salt & 5.91 & 2.16 \\
\hline
\end{tabular}

${ }^{1}$ Concentrate with low- (LC) and highly (HC) degradable carbohydrates.

${ }^{2}$ Contained per kilogram of concentrate: $6.5 \mathrm{~g}$ of $\mathrm{Ca}, 5 \mathrm{~g}$ of $\mathrm{Mg}, 3.5 \mathrm{~g}$ of Na, $13.4 \mathrm{~g}$ of K, $4.9 \mathrm{~g}$ of P, $3.2 \mathrm{~g}$ of S, $3.6 \mathrm{~g}$ of Cl, $1.6 \mathrm{mg}$ of $\mathrm{Co}, 0.3 \mathrm{mg}$ of Se, $2.3 \mathrm{mg}$ of Fe, $0.71 \mathrm{mg}$ of Mo, 10,000,000 IU of vitamin A, 2,000,000 IU of vitamin D, 10,000 IU of vitamin E.

(Blgg BV, Oosterbeek, the Netherlands). These nearinfrared reflectance spectrometry values were calibrated using the following techniques: OMD was determined according to the method of Tilley and Terry (1963) and $\mathrm{NE}_{\mathrm{L}}$ for lactating dairy cows was calculated according to Van Es (1978). The Dutch protein evaluation system as described by Tamminga et al. (1994) was used to determine DVE and OEB.

For FA analysis of feedstuffs, lipids from freezedried, ground samples were extracted with chloroformmethanol (2:1 vol/vol; Folch et al., 1957), with some modification as described by Khan et al. (2009). After extractions, FA in the residual fat were (trans)esterified, using both acid- and base-catalyzed methods as described by Khan et al. (2011). Milk FA extraction and methylation were performed as described by Jacobs et al. (2011), except that $30 \mathrm{~mL}$ of composite morning and evening (1:1) samples was used. The FA methyl esters were quantified by GC (TRACE GC Ultra; Thermo Electron Corp., Waltham, MA), equipped with a flame-ionization detector and an autosampler. Methylated FA were separated using a fused silica capillary column $(100 \mathrm{~m} \times 0.25 \mathrm{~mm}$ and $0.2-\mu \mathrm{m}$ film thickness; model RT-2560; Restek Corp., Bellefonte, PA) using hydrogen as carrier gas at a constant flow of $1.2 \mathrm{~mL} / \mathrm{min}$. One microliter of sample was injected in the GC with a split ratio of 1:100 for feedstuffs and 1:50 for milk. The following program was used for the GC: starting temperature $100^{\circ} \mathrm{C}$ for 4 min, increasing with $3^{\circ} \mathrm{C}$ per min to $240^{\circ} \mathrm{C}$, and maintaining for $10 \mathrm{~min}$ at $240^{\circ} \mathrm{C}$. The temperature of the injector was $225^{\circ} \mathrm{C}$ and the flame-ionization detector was $250^{\circ} \mathrm{C}$. Peaks were identified by comparing their retention time with those of the corresponding FA methyl ester standards S37 (Supelco Inc., Bellefonte, PA): odd and branched-chain FA; C18:1 trans-11; C18:2 cis-9,trans-11; and C18:2 trans-10,cis-12 (Larodan Fine Chemicals AB, Malmö, Sweden). Fatty acids C18:1 trans $-6+7+8$; C18:1 trans-9; C18:1 trans-10; C18:1 trans-11; C18:1 trans-12; C18:1 trans-16; C18:1 cis-12; C18:1 cis-13; C18:1 cis-14; $\mathrm{C} 18: 1$ cis-15; and $\mathrm{C} 18: 2$ trans-11,cis-15 were identified according to the elution sequence reported by Loor et al. (2004) and Shingfield et al. (2006).

\section{Statistical Analysis}

The effects of corn silage maturity, concentrate type, and lactation stage on intake of nutrients, milk yield, milk composition, body condition, and milk FA composition were determined by repeated measure ANOVA using the PROC MIXED procedure (Littell et al., 2006) of the SAS (SAS Institute, 2003). Weeks of lactation were considered as a repeated effect on individual cows. Corn silage maturity, concentrate type, and lactation stage were fixed effects and cow was considered as a random effect. Interactions were either nonsignificant or not relevant (concentrate $\times$ week), and, therefore, excluded from the model 


$$
Y_{i j k l}=\mu+M_{i}+C_{j}+W_{k}+e_{i j k l},
$$

where $Y_{i j k l}$ is the dependent variable, $\mu$ is the general mean, $M_{i}$ is the fixed effect of corn silage $(i=\mathrm{MS} 30$, MS34, MS38, or MS42), $\mathrm{C}_{j}$ is the fixed effect concentrate types $(j=\mathrm{HC}$ or $\mathrm{LC}), W_{k}$ is the fixed effect of the repeated measures of lactation weeks $(k=2$ to 15 for all variables except milk FA; for milk FA, $k=3,5$, or 10), and $e_{i j k l}$ is the residual. The different covariance structures of repeated matrices were evaluated according to Littell et al. (1998) and Wang and Goonewardene (2004) using the Akaike information criterion and the Schwarz Bayesian criterion. Based on these criterion values, the unstructured covariance structure or ANTE (1) covariance structure were used in the models. To test pairwise differences, post-hoc analyses were carried out on the least squares means adjusted for multiple comparisons using the Tukey-Kramer test.

\section{RESULTS}

\section{Feed Composition}

Data on chemical composition, feeding value, and FA contents of forage mixture ingredients and the concentrates are summarized in Table 3 . The starch content of the corn silages increased (381 to $433 \mathrm{~g} / \mathrm{kg}$ of DM), whereas the NDF content decreased (366 to $341 \mathrm{~g} / \mathrm{kg}$ of DM) consistently in silages made from the successive harvests. The content of $\mathrm{CP}$ and $\mathrm{NE}_{\mathrm{L}}$ and the $\mathrm{OMD}$ were similar across the corn silages.

Compared with corn silages, the grass silage and soybean meal were rich in $\mathrm{CP}$ and lower in starch content. The HC concentrate was higher in WSC and lower in starch and NDF compared with the LC concentrate. Maturation of the silage corn decreased the content of C16:0, C18:3n-3, PUFA, and total FA (Table 3), with the content of C18:3n-3 showing the largest decrease (1.65 to $0.58 \mathrm{~g} / \mathrm{kg}$ of DM) with maturity. The FA composition of corn silages, soybean meal, and concentrates was dominated by C18:1 cis-9 and C18:2n-6, whereas in grass silage, C18:3n-3 was the predominant FA.

\section{Nutrient Intake and Animal Performance}

Intake of $\mathrm{DM}, \mathrm{CP}$, and $\mathrm{NE}_{\mathrm{L}}$ did not differ $(P>0.05)$ with advancing maturity from MS30 to MS42 (Table $4)$. The intake of starch increased $(P<0.01)$, and those of NDF and ADF decreased $(P<0.05)$ with increasing maturation. The intake of $\mathrm{DM}$ and $\mathrm{NE}_{\mathrm{L}}$ did not vary due to concentrate type (Table 4). However, the intake of WSC was higher $(P<0.001)$ and that of NDF was lower $(P<0.001)$ on the HC compared with the LC concentrate. The intake of total FA $(P<0.01)$, PUFA
$(P<0.01)$, and $C 18: 3 n-3(P<0.001)$ decreased with increasing maturation of the corn silages. The intake of $\mathrm{C} 18: 1$ cis-9 and $\mathrm{C} 18: 2 \mathrm{n}-6$ was higher $(P<0.001)$ in the LC compared with the $\mathrm{HC}$ rations. However, the intake of C18:3n-3 did not differ due to concentrate type. Lactation stage significantly $(P<0.001)$ changed the intakes of all nutrients and FA (data not shown).

No difference in milk yield and milk composition was found between the corn silages, except for yield of fat, which significantly $(P<0.05)$ lowered in the MS42 compared with the MS34 and MS38 (Table 5). The yields $(\mathrm{kg} / \mathrm{d})$ of milk, protein, and lactose were higher $(P<0.05)$ on the LC ration compared with the $\mathrm{HC}$ ration. Advancing lactation significantly $(P<0.001)$ affected the milk yield and composition. The percentages of fat and lactose in milk were higher $(P<0.05)$ on the $\mathrm{HC}$ ration compared with the $\mathrm{LC}$ ration. Body weight and BCS over the 15-wk lactation period did not differ due to the maturity of corn silages and type of concentrates.

\section{FA Composition of Milk}

The effect of corn silages, concentrate type, and lactation stage on milk FA composition of the dairy cows is presented in Table 6. Increasing harvest-maturity of the corn silages from MS30 to MS42 decreased $(P<0.05)$ the content of C18:3n-3 and total n-3 and increased the n-6:n-3 ratio in milk fat. Moreover, increasing maturity of corn silage at harvest decreased $(P<0.05)$ the content of iso-C13:0, iso-C15:0, iso-C17:0 and total oddand branched-chain FA and increased anteiso-C17:0 in milk fat. Concentrate type significantly altered $(P$ $<0.05)$ the composition of all trans FA, except C18:2 trans-9,12 (Table 6). Inclusion of the HC concentrate in the corn silage-based diets increased the content of all C18:1-trans isomers; C18:2 cis-9,trans-11; and C18:2 trans-10,cis-12. Milk FA composition was strongly influenced by the stage of lactation (Table 6). The content of all even short- and medium-chain FA altered $(P<0.05)$, except for $\mathrm{C} 8: 0$ and $\mathrm{C} 10: 0$. The content of C12:0, C14:0, and C16:0 in total fat increased $(P<$ $0.05)$ as a result of advancing lactation with the largest increase (29.1 to $32.4 \mathrm{~g} / 100 \mathrm{~g}$ of total FA) observed for C16:0. The content of $\mathrm{C} 4: 0$ and $\mathrm{C} 6: 0$ on the other hand decreased $(P<0.05)$ with lactation. Among the preformed (not synthesized de novo) saturated FA, the content of C18:0 showed the largest decrease (9.30 to $8.88 \mathrm{~g} / 100 \mathrm{~g}$ of total FA) with lactation. Overall, the total content of saturated FA increased (70.0 to 74.8 $\mathrm{g} / 100 \mathrm{~g}$ of total FA) with advancing lactation, whereas the content of C18:1 cis total and total cis MUFA decreased with lactation. 
Table 3. Chemical composition, feeding value, and FA composition of forage ingredients and concentrates

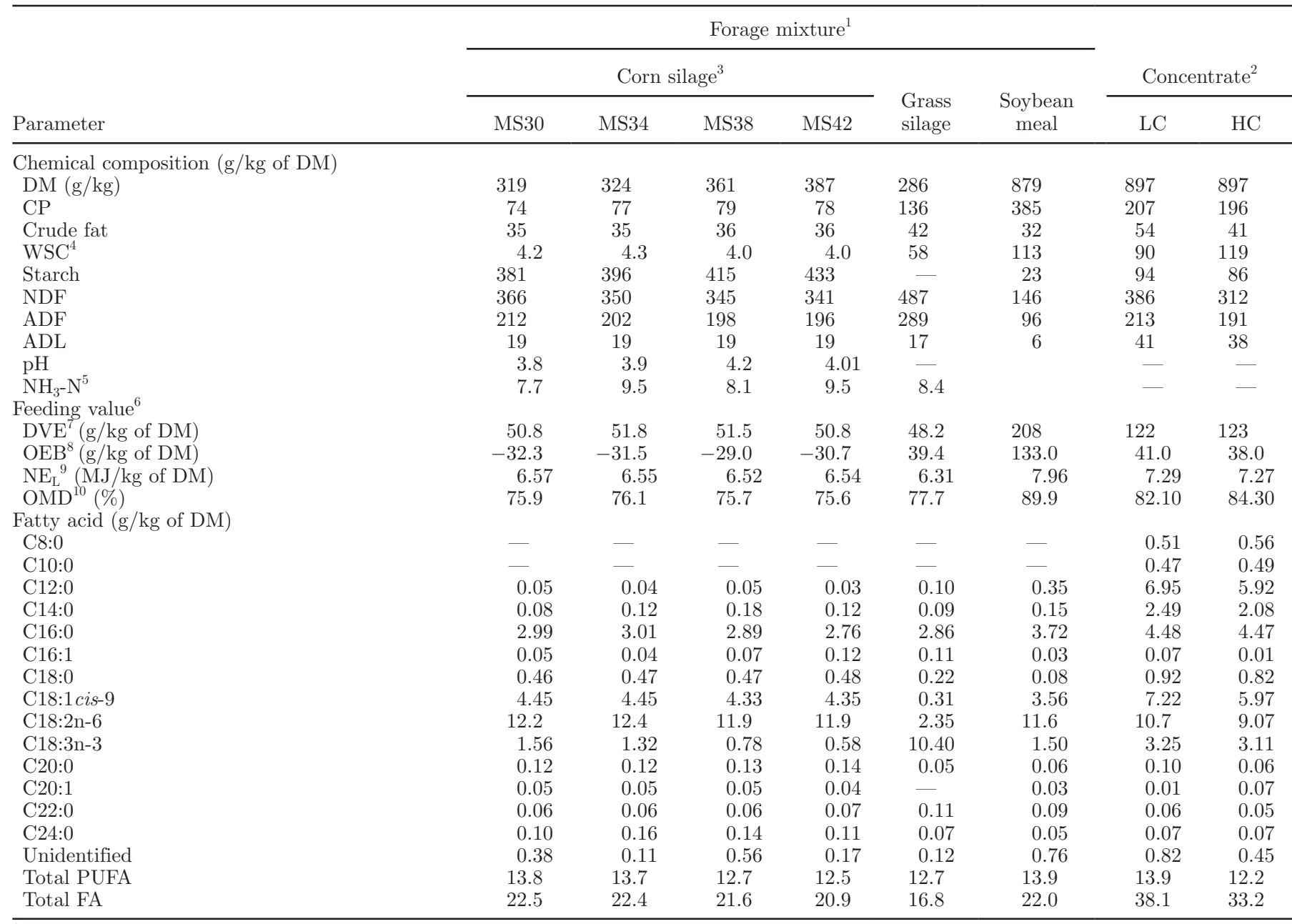

${ }^{1}$ Forage mixture contained (DM basis): $61 \%$ corn silage, $28 \%$ grass silage, $10 \%$ soybean meal, $0.45 \%$ mineral and vitamin mixture, and $0.34 \%$ salt $(\mathrm{NaCl})$.

${ }^{2}$ Concentrates with low- (LC) degradable or highly (HC) degradable carbohydrates.

${ }^{3}$ Dry matter content of 300 (MS30), 340 (MS34), 380 (MS38), and 420 (MS42) g/kg of fresh weight.

${ }^{4}$ Water-soluble carbohydrates.

${ }^{5}$ Ammonia nitrogen (g/100 g of total $\left.\mathrm{N}\right)$.

${ }^{6}$ Calculated according to CVB (2007).

${ }^{7}$ Intestinal digestible proteins (Tamminga et al., 1994).

${ }^{8}$ Degraded protein balance in the rumen (Tamminga et al., 1994).

${ }^{9}$ Net energy for lactation calculated with feed unit lactation (VEM) system (Van Es, 1978).

${ }^{10}$ Organic matter digestibility determined in vitro according to Tilley and Terry (1963) as modified by van der Meer (1986).

\section{DISCUSSION}

Research has established that the composition of carbohydrates (starch:NDF ratio; Kalscheur et al., 1997; Shingfield et al., 2005; Nielsen et al., 2006) and content of PUFA (Kelly et al., 1998; Chilliard et al., 2001) in the diets of dairy cows can alter the content and composition of milk fat. Silage corn, next to grass, is a major forage component in rations of dairy cows under most dietary regimens. The crop is harvested at an advanced ripening stage (for high starch content), but with a wide range in stage of maturation (Phipps et al., 2000; Cone et al., 2008). The variation in maturity at harvest has shown marked influences on the carbohydrate composition (starch:NDF ratio; Bal et al., 2000; Phipps et al., 2000) and FA content of corn silages (Khan et al., 2011). The current experiment aimed to provide comprehensive insight into the effect of corn ensiled at different maturities and supplemented with an $\mathrm{HC}$ and $\mathrm{LC}$ concentrate on nutrient and FA intake, 
Table 4. Effect of corn silages (MS) ensiled at different maturities in combination with a low- (LC) or highly (HC) degradable carbohydrate concentrate (Conc) on the nutrient intake of dairy cows

\begin{tabular}{|c|c|c|c|c|c|c|c|c|c|c|}
\hline \multirow[b]{2}{*}{ Parameter } & \multicolumn{4}{|c|}{ Corn silage $^{1}$} & \multirow[b]{2}{*}{ SEM } & \multicolumn{3}{|c|}{ Concentrate } & \multicolumn{2}{|c|}{ Significance $^{2}$} \\
\hline & MS30 & MS34 & MS38 & MS42 & & $\mathrm{LC}$ & $\mathrm{HC}$ & SEM & MS & Conc \\
\hline MS DM & 9.7 & 10.0 & 10.0 & 9.5 & 0.38 & 9.9 & 9.7 & 0.35 & NS & NS \\
\hline Forage DM & 15.8 & 16.4 & 16.2 & 15.5 & 0.62 & 16.1 & 15.9 & 0.57 & NS & NS \\
\hline Total DM & 23.2 & 23.5 & 23.7 & 22.8 & 0.68 & 23.4 & 23.1 & 0.64 & NS & NS \\
\hline $\mathrm{CP}$ & 3.40 & 3.47 & 3.53 & 3.40 & 0.089 & 3.52 & 3.38 & 0.085 & $\dagger$ & $* * *$ \\
\hline $\mathrm{WSC}^{3}$ & 1.27 & 1.27 & 1.29 & 1.24 & 0.028 & 1.16 & 1.38 & 0.026 & $\dagger$ & $* * *$ \\
\hline NDF & 8.58 & 8.45 & 8.39 & 8.06 & 0.238 & 8.72 & 8.02 & 0.233 & $*$ & $* * *$ \\
\hline $\mathrm{ADF}$ & 5.00 & 4.93 & 4.88 & 4.70 & 0.139 & 5.01 & 4.75 & 0.130 & $*$ & $* *$ \\
\hline $\mathrm{DVE}^{4}$ & 1.95 & 1.99 & 1.97 & 1.93 & 0.049 & 1.97 & 1.95 & 0.046 & NS & NS \\
\hline $\mathrm{NE}_{\mathrm{L}}^{5}(\mathrm{MJ} / \mathrm{d})$ & 160 & 162 & 159 & 156 & 4.4 & 161 & 159 & 4.1 & NS & NS \\
\hline \multicolumn{11}{|c|}{ Fatty acid intake $(\mathrm{g} / \mathrm{d})$} \\
\hline C8:0 & 3.94 & 3.91 & 3.97 & 3.94 & 0.040 & 3.75 & 4.12 & 0.039 & NS & $* * *$ \\
\hline C18:1 cis-9 & 98.8 & 99.4 & 99.3 & 96.7 & 2.35 & 104 & 93.3 & 2.25 & NS & $* * *$ \\
\hline $\mathrm{C} 18: 2 \mathrm{n}-6$ & 221 & 225 & 221 & 214 & 6.3 & 228 & 213 & 5.9 & $t$ & $* * *$ \\
\hline C18:3n-3 & 86.2 & 85.1 & 80.7 & 75.7 & 2.47 & 83.0 & 80.8 & 2.32 & $* * *$ & $\dagger$ \\
\hline Total PUFA & 307 & 310 & 302 & 289 & 8.8 & 311 & 294 & 8.3 & $* *$ & $* * *$ \\
\hline Total fatty acids & 590 & 592 & 592 & 566 & 14.8 & 606 & 654 & 14.0 & $* *$ & $* * *$ \\
\hline
\end{tabular}

${ }^{1}$ Dry matter contents of 300 (MS30), 340 (MS34), 380 (MS38), and 420 (MS42) g/kg of fresh matter.

${ }^{2} \dagger P<0.1,{ }^{*} P<0.05,{ }^{* *} P<0.001,{ }^{* * *} P<0.001$; weeks of lactation significantly $(P<0.001)$ influenced the intake of all nutrients.

${ }^{3}$ Water-soluble carbohydrates.

${ }^{4}$ Intestinal digestible protein (Tamminga et al., 1994).

${ }^{5}$ Net energy for lactation calculated using feed unit lactation (VEM) system (Van Es, 1978).

Table 5. Milk production, milk composition, and changes in body condition of dairy cows fed corn silages (MS) ensiled at different stages of maturity in combination with a low- (LC) and highly (HC) degradable carbohydrate concentrate (Conc) during wk 2 to 15 of lactation

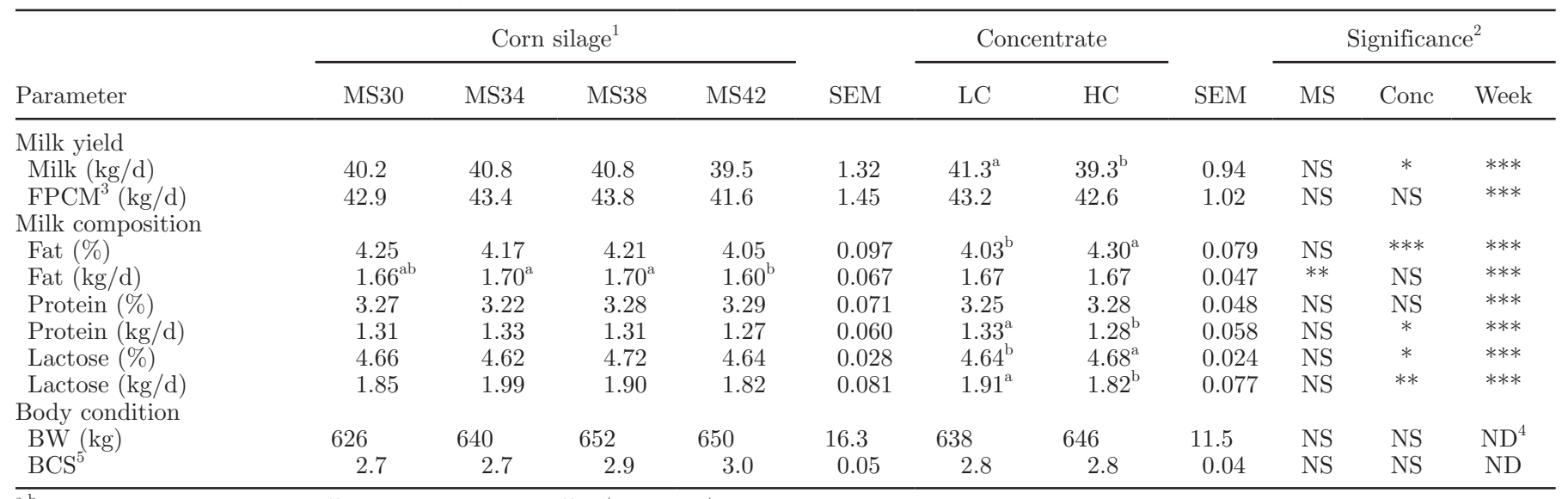

a,b Means within rows with different superscripts differ $(P<0.05)$.

${ }^{1}$ Dry matter contents of 300 (MS30), 340 (MS34), 380 (MS38), and 420 (MS42) g/kg of fresh matter.

${ }^{2} * P<0.05,{ }^{* *} P<0.001,{ }^{* * *} P<0.001$

${ }^{3}$ Fat- and protein-corrected milk.

${ }^{4}$ Not determined.

${ }^{5}$ Body condition score on a scale of 1 to 5 according to Edmonson et al. (1989). 
Table 6. Milk FA profile of dairy cows fed corn silage (MS) ensiled at different stages of maturity in combination with a low-degradable carbohydrate (LC) or a highly degradable carbohydrate (HC) concentrate (Conc) during wk 3,5 , and 10 of lactation

\begin{tabular}{|c|c|c|c|c|c|c|c|c|c|c|c|c|c|c|c|}
\hline \multirow{2}{*}{$\begin{array}{l}\text { Fatty acid } \\
(\mathrm{g} / 100 \mathrm{~g} \text { of total FA) }\end{array}$} & \multicolumn{4}{|c|}{ Corn silage $^{1}$} & \multirow[b]{2}{*}{ SEM } & \multicolumn{2}{|c|}{ Concentrate } & \multirow[b]{2}{*}{ SEM } & \multicolumn{3}{|c|}{ Stage of lactation } & \multirow[b]{2}{*}{ SEM } & \multicolumn{3}{|c|}{ Significance $^{2}$} \\
\hline & MS30 & MS34 & MS38 & M42 & & $\mathrm{HC}$ & $\mathrm{LC}$ & & Wk 3 & Wk 5 & Wk 10 & & MS & Conc & Week \\
\hline C4:0 & $3.37^{\mathrm{ab}}$ & $3.52^{\mathrm{ab}}$ & $3.53^{\mathrm{a}}$ & $3.32^{\mathrm{b}}$ & 0.061 & 3.45 & 3.41 & 0.047 & $3.55^{\mathrm{a}}$ & $3.46^{\mathrm{a}}$ & $3.29^{\mathrm{b}}$ & 0.048 & * & NS & $* * *$ \\
\hline C6:0 & 2.35 & 2.46 & 2.47 & 2.36 & 0.041 & 2.38 & 2.43 & 0.030 & $2.47^{\mathrm{a}}$ & $2.41^{\mathrm{ab}}$ & $2.34^{\mathrm{b}}$ & 0.034 & $\dagger$ & NS & $* *$ \\
\hline C8:0 & 1.50 & 1.56 & 1.57 & 1.53 & 0.038 & $1.50^{\mathrm{b}}$ & $1.58^{\mathrm{a}}$ & 0.028 & 1.58 & 1.55 & 1.49 & 0.032 & NS & $*$ & NS \\
\hline C10:0 & 3.45 & 3.62 & 3.70 & 3.63 & 0.130 & 3.49 & 3.71 & 0.095 & 3.53 & 3.62 & 3.64 & 0.106 & NS & $\dagger$ & NS \\
\hline C11:0 & 0.09 & 0.09 & 0.09 & 0.09 & 0.007 & 0.089 & 0.09 & 0.005 & $0.10^{\mathrm{a}}$ & $0.10^{\mathrm{a}}$ & $0.08^{\mathrm{b}}$ & 0.006 & NS & NS & $* *$ \\
\hline $\mathrm{C} 12: 0$ & 4.54 & 4.68 & 4.78 & 4.83 & 0.164 & $4.45^{\mathrm{b}}$ & $4.96^{\mathrm{a}}$ & 0.123 & $4.55^{\mathrm{b}}$ & $4.66^{\mathrm{ab}}$ & $4.92^{\mathrm{a}}$ & 0.085 & NS & $* *$ & $*$ \\
\hline C13:0 & 0.10 & 0.11 & 0.11 & 0.11 & 0.009 & 0.10 & 0.11 & 0.007 & 0.11 & 0.10 & 0.11 & 0.006 & NS & $\dagger$ & NS \\
\hline Iso-C13:0 & $0.01^{\mathrm{a}}$ & $0.01^{\mathrm{b}}$ & $0.01^{\mathrm{ab}}$ & $0.01^{\mathrm{ab}}$ & 0.002 & 0.01 & 0.01 & 0.002 & $0.01^{\mathrm{a}}$ & $0.01^{\mathrm{a}}$ & $0.01^{\mathrm{b}}$ & 0.001 & $*$ & NS & $* * *$ \\
\hline Anteiso-C13:0 & 0.08 & 0.08 & 0.08 & 0.09 & 0.005 & $0.08^{\mathrm{b}}$ & $0.09^{\mathrm{a}}$ & 0.004 & 0.08 & 0.08 & 0.09 & 0.004 & NS & $* *$ & NS \\
\hline C14:0 & 11.9 & 12.1 & 12.4 & 12.4 & 0.24 & 12.1 & 12.3 & 0.18 & $11.6^{\mathrm{c}}$ & $12.2^{\mathrm{b}}$ & $12.8^{\mathrm{a}}$ & 0.21 & NS & NS & $* * *$ \\
\hline Iso-C14:0 & 0.07 & 0.06 & 0.07 & 0.06 & 0.004 & 0.06 & 0.06 & 0.003 & 0.06 & 0.06 & 0.06 & 0.003 & $t$ & NS & NS \\
\hline C14:1 cis-9 & 0.91 & 0.85 & 0.91 & 0.96 & 0.041 & $0.87^{\mathrm{b}}$ & $0.95^{\mathrm{a}}$ & 0.029 & $0.85^{\mathrm{c}}$ & $0.90^{\mathrm{b}}$ & $0.98^{\mathrm{a}}$ & 0.025 & NS & $*$ & $* * *$ \\
\hline C15:0 & 0.92 & 0.98 & 0.89 & 0.98 & 0.062 & 0.94 & 0.95 & 0.050 & 0.92 & 0.92 & 0.99 & 0.050 & NS & NS & NS \\
\hline Iso-C15:0 & $0.19^{\mathrm{ab}}$ & $0.19^{\mathrm{ab}}$ & $0.20^{\mathrm{a}}$ & $0.17^{\mathrm{b}}$ & 0.008 & 0.18 & 0.19 & 0.001 & $0.18^{\mathrm{b}}$ & $0.19^{\mathrm{ab}}$ & $0.193^{\mathrm{a}}$ & 0.007 & $*$ & $t$ & $*$ \\
\hline Anteiso-C15:0 & 0.40 & 0.41 & 0.40 & 0.39 & 0.017 & 0.40 & 0.41 & 0.015 & $0.39^{\mathrm{ab}}$ & $0.40^{\mathrm{b}}$ & $0.42^{\mathrm{a}}$ & 0.015 & NS & NS & $*$ \\
\hline C16:0 & 30.4 & 30.7 & 30.3 & 31.0 & 0.59 & $31.5^{\mathrm{a}}$ & $29.8^{\mathrm{b}}$ & 0.05 & $29.1^{\mathrm{c}}$ & $30.3^{\mathrm{b}}$ & $32.4^{\mathrm{a}}$ & 0.45 & NS & $* *$ & $* * *$ \\
\hline Iso-C16:0 & 0.16 & 0.15 & 0.16 & 0.15 & 0.007 & 0.16 & 0.16 & 0.006 & 0.16 & 0.16 & 0.15 & 0.007 & NS & NS & NS \\
\hline C16:1 cis-9 & $1.53^{\mathrm{b}}$ & $1.62^{\mathrm{ab}}$ & $1.66^{\mathrm{ab}}$ & $1.78^{\mathrm{a}}$ & 0.095 & $1.70^{\mathrm{a}}$ & $1.59^{\mathrm{b}}$ & 0.080 & $1.94^{\mathrm{a}}$ & $1.99^{\mathrm{a}}$ & $1.84^{\mathrm{b}}$ & 0.075 & NS & NS & $* * *$ \\
\hline $\mathrm{C} 17: 0$ & 0.61 & 0.61 & 0.61 & 0.62 & 0.016 & 0.61 & 0.61 & 0.013 & 0.62 & 0.61 & 0.60 & 0.012 & NS & NS & NS \\
\hline Iso-C17:0 & $0.37^{\mathrm{a}}$ & $0.36^{\mathrm{a}}$ & $0.37^{\mathrm{ab}}$ & $0.34^{\mathrm{b}}$ & 0.029 & 0.36 & 0.36 & 0.029 & 0.42 & 0.34 & 0.33 & 0.042 & $*$ & NS & NS \\
\hline Anteiso-C17:0 & $0.15^{\mathrm{b}}$ & $0.17^{\mathrm{ab}}$ & $0.17^{\mathrm{ab}}$ & $0.19^{\mathrm{a}}$ & 0.019 & 0.18 & 0.19 & 0.015 & $0.20^{\mathrm{a}}$ & $0.20^{\mathrm{a}}$ & $0.16^{\mathrm{b}}$ & 0.014 & NS & NS & $* * *$ \\
\hline $\mathrm{C} 17: 1$ cis-9 & 0.24 & 0.24 & 0.22 & 0.24 & 0.012 & 0.24 & 0.23 & 0.009 & $0.27^{\mathrm{a}}$ & $0.24^{\mathrm{b}}$ & $0.19^{c}$ & 0.009 & NS & NS & $* * *$ \\
\hline C18:0 & 9.27 & 9.12 & 9.35 & 8.86 & 0.251 & 9.16 & 9.13 & 0.19 & $9.30^{\mathrm{a}}$ & $9.26^{\mathrm{a}}$ & $8.88^{\mathrm{b}}$ & 0.19 & NS & NS & $*$ \\
\hline C18:1 cis-9 & 19.0 & 17.8 & 17.7 & 18.2 & 0.671 & 18.0 & 18.3 & 0.552 & $19.3^{\mathrm{a}}$ & $18.7^{\mathrm{a}}$ & $16.6^{\mathrm{b}}$ & 0.665 & NS & NS & $* * *$ \\
\hline C18:1 cis-total $^{3}$ & 20.1 & 18.9 & 18.8 & 18.2 & 0.70 & 19.1 & 19.5 & 0.57 & $20.5^{\mathrm{a}}$ & $19.8^{\mathrm{a}}$ & $17.5^{\mathrm{b}}$ & 0.43 & NS & NS & $* * *$ \\
\hline C18:1 trans $-6+8$ & 0.23 & 0.22 & 0.22 & 0.22 & 0.009 & $0.21^{\mathrm{b}}$ & $0.24^{\mathrm{a}}$ & 0.007 & 0.22 & 0.22 & 0.22 & 0.006 & NS & $* *$ & NS \\
\hline C18:1 trans-9 & 0.16 & 0.16 & 0.16 & 0.17 & 0.004 & $0.15^{\mathrm{b}}$ & $0.17^{\mathrm{a}}$ & 0.003 & $0.16^{\mathrm{b}}$ & $0.16^{\mathrm{ab}}$ & $0.17^{\mathrm{a}}$ & 0.003 & NS & $* * *$ & $*$ \\
\hline $\mathrm{C} 18: 1$ trans $-10+11$ & 1.18 & 1.12 & 1.13 & 1.11 & 0.052 & $1.05^{\mathrm{b}}$ & $1.22^{\mathrm{a}}$ & 0.038 & 1.18 & 1.12 & 1.10 & 0.030 & NS & $* *$ & $\dagger$ \\
\hline C18:1 trans-12 & 0.30 & 0.31 & 0.30 & 0.30 & 0.009 & $0.28^{\mathrm{b}}$ & $0.33^{\mathrm{a}}$ & 0.007 & 0.30 & 0.30 & 0.31 & 0.007 & NS & $* * *$ & NS \\
\hline C18:1 trans-total $^{4}$ & 2.16 & 2.14 & 2.12 & 2.09 & 0.076 & $1.99^{\mathrm{b}}$ & $2.27^{\mathrm{a}}$ & 0.054 & 2.16 & 2.11 & 2.12 & 0.055 & NS & $* * *$ & NS \\
\hline C18:1 trans $-16+$ cis- 14 & 0.31 & 0.31 & 0.31 & 0.29 & 0.008 & $0.30^{\mathrm{b}}$ & $0.31^{\mathrm{a}}$ & 0.007 & 0.30 & 0.30 & 0.31 & 0.007 & $\dagger$ & NS & NS \\
\hline C18:2 trans $-9,12$ & $0.15^{\mathrm{b}}$ & $0.13^{\mathrm{b}}$ & $0.13^{\mathrm{b}}$ & $0.16^{\mathrm{a}}$ & 0.008 & 0.15 & 0.14 & 0.006 & $0.16^{\mathrm{a}}$ & $0.17^{\mathrm{a}}$ & $0.09^{\mathrm{b}}$ & 0.005 & $*$ & NS & $* * *$ \\
\hline C18:2 cis-9,12 (n-6) & 1.78 & 1.71 & 1.75 & 1.74 & 0.038 & 1.71 & 1.78 & 0.027 & $1.70^{\mathrm{b}}$ & $1.76^{\mathrm{a}}$ & $1.78^{\mathrm{a}}$ & 0.027 & NS & NS & $* *$ \\
\hline 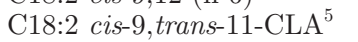 & 0.35 & 0.34 & 0.31 & 0.32 & 0.011 & $0.32^{\mathrm{b}}$ & $0.34^{\mathrm{a}}$ & 0.007 & 0.35 & 0.33 & 0.32 & 0.007 & NS & $*$ & $*$ \\
\hline C18:2 trans-10, cis-12-CLA & 0.01 & 0.01 & 0.01 & 0.01 & 0.002 & $0.01^{\mathrm{b}}$ & $0.01^{\mathrm{a}}$ & 0.002 & $0.01^{\mathrm{b}}$ & $0.03^{\mathrm{c}}$ & $0.01^{\mathrm{a}}$ & 0.001 & NS & ** & $* * *$ \\
\hline C18:3n-3 & $0.42^{\mathrm{a}}$ & $0.39^{\mathrm{ab}}$ & $0.39^{\mathrm{ab}}$ & $0.37^{\mathrm{b}}$ & 0.010 & 0.39 & 0.40 & 0.007 & 0.40 & 0.40 & 0.39 & 0.007 & $* *$ & NS & NS \\
\hline C18:3n-6 & $0.01^{\mathrm{b}}$ & $0.02^{\mathrm{b}}$ & $0.02^{\mathrm{ab}}$ & $0.02^{\mathrm{a}}$ & 0.002 & 0.02 & 0.02 & 0.002 & $0.01^{\mathrm{b}}$ & $0.02^{\mathrm{a}}$ & $0.03^{\mathrm{a}}$ & 0.001 & $* * *$ & NS & $* * *$ \\
\hline $\mathrm{C} 20: 0$ & $0.10^{\mathrm{b}}$ & $0.10^{\mathrm{b}}$ & $0.11^{\mathrm{ab}}$ & $0.12^{\mathrm{a}}$ & 0.006 & 0.11 & 0.11 & 0.053 & 0.11 & 0.10 & 0.12 & 0.006 & $* *$ & NS & $t$ \\
\hline $\mathrm{C} 20: 1$ cis- 11 & $0.06^{\mathrm{ac}}$ & $0.05^{\mathrm{b}}$ & $0.06^{\mathrm{bc}}$ & $0.07^{\mathrm{a}}$ & 0.003 & 0.06 & 0.06 & 0.002 & $0.06^{\mathrm{b}}$ & $0.07^{\mathrm{a}}$ & $0.06^{\mathrm{b}}$ & 0.002 & $* * *$ & NS & $* * *$ \\
\hline $\mathrm{C} 20: 2 \mathrm{n}-6$ & $0.00^{\mathrm{b}}$ & $0.01^{\mathrm{ab}}$ & $0.01^{\mathrm{ab}}$ & $0.01^{\mathrm{a}}$ & 0.001 & 0.01 & 0.01 & 0.001 & 0.01 & 0.01 & 0.01 & 0.001 & $*$ & NS & NS \\
\hline$C 20: 3 n-6$ & 0.07 & 0.07 & 0.07 & 0.08 & 0.004 & $0.07^{\mathrm{b}}$ & $0.08^{\mathrm{a}}$ & 0.003 & $0.06^{\mathrm{c}}$ & $0.07^{\mathrm{b}}$ & $0.08^{\mathrm{a}}$ & 0.003 & NS & $*$ & $* * *$ \\
\hline $\mathrm{C} 20: 4 n-6$ & $0.05^{\mathrm{b}}$ & $0.07^{\mathrm{a}}$ & $0.07^{\mathrm{a}}$ & $0.06^{\mathrm{a}}$ & 0.003 & $0.06^{\mathrm{b}}$ & $0.07^{\mathrm{a}}$ & 0.003 & $0.09^{\mathrm{a}}$ & $0.02^{\mathrm{b}}$ & $0.07^{\mathrm{a}}$ & 0.003 & $* * *$ & $* *$ & $* * *$ \\
\hline $\mathrm{C} 20: 5 \mathrm{n}-3$ & 0.04 & 0.04 & 0.04 & 0.05 & 0.002 & 0.04 & 0.04 & 0.002 & $0.05^{\mathrm{a}}$ & $0.04^{\mathrm{ab}}$ & $0.04^{\mathrm{b}}$ & 0.002 & NS & NS & * \\
\hline $\mathrm{C} 22: 0$ & 0.03 & 0.02 & 0.03 & 0.03 & 0.001 & 0.03 & 0.03 & 0.001 & 0.03 & 0.02 & 0.03 & 0.001 & NS & NS & NS \\
\hline $\mathrm{C} 22: 2 \mathrm{n}-3$ & 0.02 & 0.02 & 0.01 & 0.02 & 0.002 & 0.02 & 0.02 & 0.002 & 0.01 & 0.01 & 0.02 & 0.001 & NS & NS & NS \\
\hline C22:5n-3 & 0.06 & 0.06 & 0.06 & 0.06 & 0.004 & 0.06 & 0.06 & 0.004 & 0.06 & 0.06 & 0.06 & 0.004 & NS & NS & NS \\
\hline $\mathrm{C} 24: 0$ & 0.02 & 0.01 & 0.01 & 0.02 & 0.002 & 0.01 & 0.01 & 0.002 & 0.02 & 0.01 & 0.02 & 0.002 & NS & NS & NS \\
\hline Total saturated FA & 71.5 & 73.0 & 73.0 & 72.3 & 0.73 & 72.9 & 72.0 & 0.61 & $70.0^{\mathrm{c}}$ & $72.6^{\mathrm{b}}$ & $74.8^{\mathrm{a}}$ & 0.77 & NS & $t$ & $* * *$ \\
\hline Total cis-MUFA & 21.87 & 20.6 & 20.3 & 20.9 & 0.69 & 20.7 & 21.2 & 0.56 & $22.7^{\mathrm{a}}$ & $21.2^{\mathrm{b}}$ & $18.9^{\mathrm{c}}$ & 0.73 & NS & NS & $* * *$ \\
\hline
\end{tabular}


milk production, and composition of milk and milk fat of dairy cows during early lactation.

The range of maturities (DM content of 300 to 420 $\mathrm{g} / \mathrm{kg}$ of $\mathrm{FW}$ ) chosen in the present study spanned that normally found in the Netherlands. The increase in starch content with each subsequent harvest is related to the growth of ear and deposition of starch in the grains during maturation (Cone et al., 2008). The substantial increase in starch (grain) content decreased the NDF content in the whole-crop DM. The NDF content of the stover (leaves and stems) increases as maturity advances; however, the NDF content of the whole crop decreases because the proportion of grains in the whole crop DM increases (Bal et al., 2000). The decrease in C18:3n-3 and PUFA content with maturation can be related to the decrease in $\mathrm{C} 18: 3 \mathrm{n}-3$ content in the stover fraction of corn plants during post-flowering maturation. In corn plants, the membrane glycerolipids are the main pool of $\mathrm{C} 18: 3 \mathrm{n}-3$, whereas $\mathrm{C} 18: 1$ cis-9 and $\mathrm{C} 18: 2 \mathrm{n}-6$ are the predominant FA in storage lipids (grains). During grain filling, the content of C18:3n-3 substantially decreases due to a decreasing proportion of the stover in the whole-plant DM and the decreasing FA content in the stover (Khan et al., 2011), due to rapid senescence of leaves (Struik, 1983). During leaf senescence, the membrane glycerolipids are oxidized by plant lipoxygenases, causing a rapid decrease in chloroplast FA, particularly in C18:3n-3 (Thompson et al., 1998; Mishra and Sangwan, 2008; Yang and Ohlrogge, 2009).

The lack of differences in DMI, milk yield, and body condition due to maturity of the corn supports earlier findings (Bal et al., 2000; Phipps et al., 2000). The increase in starch:NDF ratio resulted in a numeric decrease in milk fat content from $4.25 \%$ for the MS30 to $4.05 \%$ for the MS42 silage. The combination of the $\mathrm{HC}$ concentrate with corn silages resulted in a higher percentage of milk fat compared with the LC concentrate (4.30 vs. 4.03$)$. Typically, the combination of the $\mathrm{HC}$ concentrate and the low-NDF corn silage-based diets are associated with a decrease in milk fat (Nielsen et al., 2006). The high milk fat content with the HC concentrate may be due to the large $(2 \mathrm{~kg} / \mathrm{d})$ decrease in milk yield. Moreover, the fat yield did not differ between the $\mathrm{HC}$ and $\mathrm{LC}$ concentrates.

The decrease in C18:3n-3 and total n-3 content and the increase in the n-6:n-3 PUFA ratio in milk fat with maturity can be related to the parallel decrease in the intake of C18:3n-3 with maturation of corn silages. Although small differences occurred in the intake of C18:3n-3, these were reflected in the milk fat composition, which may be due to a lower degradation of the mature leaves of the corn. The apparent recovery of C18:3n-3 and C18:2n-6 from ration into milk were 8 
and $13 \%$, respectively. However, the transfer efficiency did not change with the maturity of the corn silages. The variation in odd- and branched-chain FA in milk can be used to identify shifts in the rumen microbial population, as these FA are predominantly of bacterial origin. The decrease in odd chain-iso and total odd- and branched-chain FA content in milk fat with advancing maturity of corn silages can be related to the decrease in NDF and increase in starch intake with maturation. The increase in starch:NDF ratio in the diet decreases the relative abundance of cellulolytic bacteria containing large amounts of iso-FA, compared with amylolytic bacteria (Vlaeminck et al., 2006a,b). The changes in carbohydrate composition during maturation, however, did probably not alter the hydrogenation of dietary PUFA. A plausible explanation for this effect is the relatively small variation in starch:NDF ratio due to maturation from DM content 300 to 420 $\mathrm{g} / \mathrm{kg}$ of FW. A large variation in starch:NDF ratio occurs early during the grain-filling period, with the DM content ranging from 250 to $320 \mathrm{~g} / \mathrm{kg}$ of FW (Cone et al., 2008). The present study did not include early harvested corn. Concentrate type significantly influenced the composition of milk trans FA. With the exception of $\mathrm{C} 18: 2$ cis-9,trans-11, which can also be produced via $\Delta^{9}$-stearoyl-CoA desaturase in the mammary gland (Corl et al., 2002; Piperova et al., 2002), the variation in the contents of trans isomers of C18:1 and C18:2 in milk between the 2 types of concentrates directly reflect the changes in ruminal biohydrogenation of dietary PUFA. Large amounts of PUFA or rapidly degradable carbohydrates in the diet can shift rumen biohydrogenation of PUFA toward the production of more trans FA, in particular the trans-10 isomer (Griinari et al., 1998; Shingfield et al., 2005; Nielsen et al., 2006). In the present study, the intake of $\mathrm{C} 18: 2 \mathrm{n}-6$ and C18:3n-3 was higher when the LC concentrate was fed, yet the amount of trans FA in milk were higher with the HC concentrate. This indicates that the alteration in milk trans FA composition was mainly related to the variation in carbohydrate degradation between the 2 concentrates. Diets that provide large amounts of readily degradable carbohydrates usually shift the biohydrogenation of dietary PUFA toward trans isomers by changing bacterial population (Griinari et al., 1998; Jurjanz et al., 2004).

The increase in medium chain saturated FA (C12C16:0) and decrease in $\mathrm{C} 18: 0$ and $\mathrm{C} 18: 1$ cis-9 with advancing lactation is consistent with earlier findings (Kay et al., 2005; Garnsworthy et al., 2006; Stoop et al., 2009). High-producing dairy cows are usually in a negative energy balance during early lactation and mobilize considerable amounts of body fat (Palmquist et al., 1993), containing C18:0 and C18:1 cis-9 as the predominant FA (Christie, 1981). This can explain the decrease in C18:0 by 4.5 and C18:1 cis- 9 by $14.0 \mathrm{~g} / 100$ $\mathrm{g}$ of FA between wk 3 and 10 of lactation. Moreover, a high uptake of long-chain FA inhibits de novo lipogenesis, particularly of the medium-chain saturated FA.

\section{CONCLUSIONS}

Increasing corn harvest maturity (crop DM content 300 to $420 \mathrm{~g} / \mathrm{kg}$ of FM) at ensilaging did not affect the DMI, milk yield, and BCS, but decreased the content of $C 18: 3 n-3$ and total $n-3$ and increased the $n-6: n-3$ ratio in milk fat of dairy cows. The combination of corn silage and an $\mathrm{HC}$ concentrate increased the content of all C18:1 trans isomers, C18:2 cis-9,trans-11, C18:2 trans-10, cis-12, and total trans FA in milk fat compared with an LC concentrate. Milk FA composition was significantly influenced by stage of lactation. The content of C12:0, C14:0, and C16:0 and total saturated FA increased, whereas the content of C18:0, C18:1-cis total, and total cis-MUFA decreased with advancing lactation.

\section{ACKNOWLEDGMENTS}

The authors thank the staff of Wageningen University and Research Center (Lelystad, the Netherlands) and the laboratory of the Animal Nutrition group for technical assistance. Financial support was provided by the Higher Education Commission of Pakistan, Royal Friesland-Campina (Meppel, the Netherlands), and CCL Nutricontrol (Veghel, the Netherlands).

\section{REFERENCES}

Ascherio, A., M. B. Katan, P. L. Zock, M. J. Stampfer, and W. C. Willett. 1999. Trans fatty acids and coronary heart disease. N. Engl. J. Med. 340:1994-1998.

Bal, M. A., R. D. Shaver, A. G. Jirovec, K. J. Shinners, and J. G. Coors. 2000. Crop processing and chop length of corn silage: Effects on intake, digestion, and milk production by dairy cows. J. Dairy Sci. 83:1264-1273.

Barrière, Y., D. Alber, O. Dolstra, C. Lapierre, M. Motto, A. Ordas, J. Van Waes, L. Vlasminkel, C. Welcker, and J. P. Monod. 2006. Past and prospects of forage maize breeding in Europe. II. History, germplasm evolution and correlative agronomic changes. Maydica 51:435-449.

Chilliard, Y., A. Ferlay, and M. Doreau. 2001. Effect of different types of forages, animal fat or marine oils in cow's diet on milk fat secretion and composition, especially conjugated linoleic acid (CLA) and polyunsaturated fatty acids. Livest. Prod. Sci. 70:31-48.

Christie, W. W. 1981. The composition, structure and function of lipids in the tissues of ruminant animals. Pages 95-191 in Lipid Metabolism in Ruminant Animals. W. W. Christie, ed. Pergamon Press, Oxford, UK.

Cone, J. W., A. H. Van Gelder, H. A. Van Schooten, and J. A. M. Groten. 2008. Effects of forage maize type and maturity stage on in vitro rumen fermentation characteristics. Neth. J. Agric. Sci. 55:139-154.

Corl, B. A., L. H. Baumgard, J. M. Griinari, P. Delmonte, K. M. Morehouse, M. P. Yurawecz, and D. E. Bauman. 2002. Trans- 
7,cis-9 CLA is synthesized endogenously by $\delta 9$-desaturase in dairy cows. Lipids 37:681-688.

CVB (Central Bureau for Livestock Feeding). 2007. Table Ruminants, chemical composition and nutritional values of feedstuffs and feeding standards, Series no 32. CVB, The Hague, the Netherlands.

Dewhurst, R. J., K. J. Shingfield, M. R. F. Lee, and N. D. Scollan. 2006. Increasing the concentrations of beneficial polyunsaturated fatty acids in milk produced by dairy cows in high-forage systems. Anim. Feed Sci. Technol. 131:168-206.

Edmonson, A. J., I. J. Lean, L. D. Weaver, T. Farver, and G. Webster. 1989. A body condition scoring chart for Holstein dairy cows. J. Dairy Sci. 72:68-78.

Elgersma, A., S. Tamminga, and G. Ellen. 2006. Modifying milk composition through forage. Anim. Feed Sci. Technol. 131:207-225.

Folch, J., M. Lees, and G. H. Sloane Stanley. 1957. A simple method for the isolation and purification of total lipides from animal tissues. J. Biol. Chem. 226:497-509.

Garnsworthy, P. C., L. L. Masson, A. L. Lock, and T. T. Mottram. 2006. Variation of milk citrate with stage of lactation and de novo fatty acid synthesis in dairy cows. J. Dairy Sci. 89:1604-1612.

Griinari, J. M., D. A. Dwyer, M. A. McGuire, D. E. Bauman, D. L. Palmquist, and K. V. V. Nurmela. 1998. Trans-octadecenoic acids and milk fat depression in lactating dairy cows. J. Dairy Sci. 81:1251-1261.

Havemose, M. S., M. R. Weisbjerg, W. L. P. Bredie, and J. H. Nielsen. 2004. Influence of feeding different types of roughage on the oxidative stability of milk. Int. Dairy J. 14:563-570.

ISO. 1999a. Animal feeding stuffs. Determination of moisture and other volatile matter content. ISO 6496. International Organization for Standardization, Geneva, Switzerland.

ISO. 1999b. Animal feeding stuffs. Determination of fat content. ISO 6492. International Organization for Standardization, Geneva, Switzerland.

ISO. 2002. Animal feeding stuffs. Determination of crude ash. ISO 5984. International Organization for Standardization, Geneva, Switzerland.

ISO. 2004. Animal feeding stuffs. Enzymatic determination of total starch content. ISO 15914. International Organization for Standardization, Geneva, Switzerland.

ISO. 2005. Animal feeding stuffs. Determination of nitrogen content and calculation of crude protein content-Kjeldahl method. ISO 5983. International Organization for Standardization, Geneva, Switzerland

Jacobs, A. A. A., J. van Baal, M. A. Smits, H. Z. H. Taweel, W. H. Hendriks, A. M. van Vuuren, and J. Dijkstra. 2011. Effects of feeding rapeseed oil, soybean oil, or linseed oil on stearoyl-CoA desaturase expression in the mammary gland of dairy cows. J. Dairy Sci. 94:874-887.

Jurjanz, S., V. Monteils, P. Juaneda, and F. Laurent. 2004. Variations of trans octadecenoic acid in milk fat induced by feeding different starch-based diets to cows. Lipids 39:19-24.

Kalscheur, K. F., B. B. Teter, L. S. Piperova, and R. A. Erdman 1997. Effect of dietary forage concentration and buffer addition on duodenal flow of trans-C18:1 fatty acids and milk fat production in dairy cows. J. Dairy Sci. 80:2104-2114.

Kay, J. K., W. J. Weber, C. E. Moore, D. E. Bauman, L. B. Hansen, H. Chester-Jones, B. A. Crooker, and L. H. Baumgard. 2005 Effects of week of lactation and genetic selection for milk yield on milk fatty acid composition in Holstein cows. J. Dairy Sci. 88:3886-3893

Kelly, M. L., J. R. Berry, D. A. Dwyer, J. M. Griinari, P. Y. Chouinard, M. E. Van Amburgh, and D. E. Bauman. 1998. Dietary fatty acid sources affect conjugated linoleic acid concentrations in milk from lactating dairy cows. J. Nutr. 128:881-885.

Khan, N. A., J. W. Cone, V. Fievez, and W. H. Hendriks. 2012. Causes of variation in fatty acid content and composition in grass and maize silages. Anim. Feed Sci. Technol. In press.

Khan, N. A., J. W. Cone, and W. H. Hendriks. 2009. Stability of fatty acids in grass and maize silages after exposure to air during the feed out period. Anim. Feed Sci. Technol. 154:183-192.
Khan, N. A., J. W. Cone, W. F. Pellikaan, M. A. Khan, P. C. Struik, and W. H. Hendriks. 2011. Changes in fatty acid content and composition in silage maize during grain filling. J. Sci. Food Agric. 91:1041-1049

Kliem, K. E., R. Morgan, D. J. Humphries, K. J. Shingfield, and D. I. Givens. 2008. Effect of replacing grass silage with maize silage in the diet on bovine milk fatty acid composition. Animal $2: 1850-1858$.

Lemaitre, R. N., I. B. King, T. E. Raghunathan, R. M. Pearce, S Weinmann, R. H. Knopp, M. K. Copass, L. A. Cobb, and D. S. Siscovick. 2002. Cell membrane trans-fatty acids and the risk of primary cardiac arrest. Circulation 105:697-701.

Littell, R. C., P. R. Henry, and C. B. Ammerman. 1998. Statistical analysis of repeated measures data using SAS procedures. J. Anim. Sci. 76:1216-1231.

Littell, R. C., G. A. Milliken, W. W. Stroup, R. D. Wolfinger, and O. Schabenberger. 2006. 2nd ed. SAS System for Mixed Models. SAS Institute Inc., Cary, NC.

Loor, J. J., K. Ueda, A. Ferlay, Y. Chilliard, and M. Doreau. 2004. Biohydrogenation, duodenal flow, and intestinal digestibility of trans fatty acids and conjugated linoleic acids in response to dietary forage:concentrate ratio and linseed oil in dairy cows. J. Dairy Sci. 87:2472-2485.

Mishra, S., and R. S. Sangwan. 2008. Changes in fatty acid composition of polar lipids associated with growth and senescence in leaves of Catharanthus roseus. Afr. J. Plant Sci. 2:34-37.

Nielsen, T. S., E. M. Straarup, M. Vestergaard, and K. Sejrsen. 2006 Effect of silage type and concentrate level on conjugated linoleic acids, trans-C18:1 isomers and fat content in milk from dairy cows. Reprod. Nutr. Dev. 46:699-712.

O'Mara, F. P., J. J. Fitzgerald, J. J. Murphy, and M. Rath. 1998 The effect on milk production of replacing grass silage with maize silage in the diet of dairy cows. Livest. Prod. Sci. 55:79-87.

Palmquist, D. L., A. D. Beaulieu, and D. M. Barbano. 1993. Feed and animal factors influencing milk fat composition. J. Dairy Sci $76: 1753-1771$.

Phipps, R. H., J. D. Sutton, D. E. Beever, and A. K. Jones. 2000. The effect of crop maturity on the nutritional value of maize silage for lactating dairy cows 3. Food intake and milk production. Anim. Sci. 71:401-409.

Phipps, R. H., J. D. Sutton, and B. A. Jones. 1995. Forage mixtures for dairy cows: The effect on dry-matter intake and milk production of incorporating either fermented or urea-treated whole-crop wheat, brewers' grains, fodder beet or maize silage into diets based on grass silage. Anim. Sci. 61:491-496.

Piperova, L. S., J. Sampugna, B. B. Teter, K. F. Kalscheur, M. P. Yurawecz, Y. Ku, K. M. Morehouse, and R. A. Erdman. 2002. Duodenal and milk trans octadecenoic acid and conjugated linoleic acid (CLA) isomers indicate that postabsorptive synthesis is the predominant source of cis-9-containing CLA in lactating dairy cows. J. Nutr. 132:1235-1241.

Piperova, L. S., B. B. Teter, I. Bruckental, J. Sampugna, S. E. Mills, M. P. Yurawecz, J. Fritsche, K. Ku, and R. A. Erdman. 2000 Mammary lipogenic enzyme activity, trans fatty acids and conjugated linoleic acids are altered in lactating dairy cows fed a milk fat-depressing diet. J. Nutr. 130:2568-2574.

SAS Institute. 2003. Statistical Analysis System, Version 9.2. SAS Institute Inc., Cary, NC.

Scheiner, D. 1976. Determination of ammonia and Kjeldahl nitrogen by indophenol method. Water Res. 10:31-36.

Schroeder, J. 1998. Towards improved nitrogen management in silage maize production on sandy soils. PhD Thesis. Wageningen University, Wageningen, the Netherlands.

Shingfield, K. J., C. K. Reynolds, G. Hervás, J. M. Griinari, A. S. Grandison, and D. E. Beever. 2006. Examination of the persistency of milk fatty acid composition responses to fish oil and sunflower oil in the diet of dairy cows. J. Dairy Sci. 89:714-732.

Shingfield, K. J., C. K. Reynolds, B. Lupoli, V. Toivonen, M. P. Yurawecz, P. Delmonte, J. M. Griinari, A. S. Grandison, and D. E. Beever. 2005. Effect of forage type and proportion of concentrate 
in the diet on milk fatty acid composition in cows given sunflower oil and fish oil. Anim. Sci. 80:225-238.

Sibma, L. 1987. Growth and Development of Maize (Zea mays L.) under Dutch Conditions. Pudoc, Wageningen, the Netherlands. (in Dutch).

Stoop, W. M., H. Bovenhuis, J. M. L. Heck, and J. A. M. Van Arendonk. 2009. Effect of lactation stage and energy status on milk fat composition of Holstein-Friesian cows. J. Dairy Sci. 92:1469-1478.

Struik, P. C. 1983. Effect of temperature on development, dry-matter production, dry- matter distribution and quality of forage maize (Zea mays L.): An analysis. PhD Thesis. Wageningen University, Wageningen, the Netherlands.

Tamminga, S., W. M. Van Straalen, A. P. J. Subnel, R. G. M. Meijer, A. Steg, C. J. G. Wever, and M. C. Blok. 1994. The Dutch protein evaluation system: The DVE/OEB-system. Livest. Prod. Sci. 40:139-155.

Thompson, J. E., C. D. Froese, E. Madey, M. D. Smith, and Y. Hong. 1998. Lipid metabolism during plant senescence. Prog. Lipid Res. $37: 119-141$

Tilley, J. M. A., and R. A. Terry. 1963. A two-stage technique for the in vitro digestion of forage crops. J. Br. Grassl. Soc. 18:104-111.

van der Meer, J. M. 1986. Optimal Prediction of in vivo Organic Matter Digestibility for Ruminants by in vitro Methods. Report No. 177. Research Institute of Livestock Feeding and Nutrition, Lelystad, the Netherlands.

Van Es, A. J. H. 1978. Feed evaluation for ruminants. I. The systems in use from May 1977-onwards in The Netherlands. Livest. Prod. Sci. 5:331-345.
Van Soest, P. J. 1973. Collaborative study of acid detergent fiber and lignin. J. Assoc. Off. Anal. Chem. 56:781-784.

Van Soest, P. J., J. B. Robertson, and B. A. Lewis. 1991. Methods for dietary fiber, neutral detergent fiber and non starch polysaccharides in relation to animal nutrition. J. Dairy Sci. 73:3583-3593.

Van Vuuren, A. M., C. J. Van der Koelen, H. Valk, and H. de Visser. 1993. Effects of partial replacement of ryegrass by low protein feeds on rumen fermentation and nitrogen loss by dairy cows. J. Dairy Sci. 76:2982-2993.

Vlaeminck, B., V. Fievez, A. R. J. Cabrita, A. J. M. Fonseca, and R. J. Dewhurst. 2006a. Factors affecting odd- and branched-chain fatty acids in milk: A review. Anim. Feed Sci. Technol. 131:389-417.

Vlaeminck, B., V. Fievez, D. Demeyer, and R. J. Dewhurst. 2006b. Effect of forage:concentrate ratio on fatty acid composition of rumen bacteria isolated from ruminal and duodenal digesta. J. Dairy Sci. 89:2668-2678.

Wang, Z., and L. A. Goonewardene. 2004. The use of MIXED models in the analysis of animal experiments with repeated measures data. Can. J. Anim. Sci. 84:1-11.

Yang, Z., and J. B. Ohlrogge. 2009. Turnover of fatty acids during natural senescence of Arabidopsis, Brachypodium, and switchgrass and in Arabidopsis oxidation mutants. Plant Physiol. 150:1981-1989. 